\title{
Az első magyar köztársaság születése: Budapest 1918. november 16.
}

\author{
Vizi László Tamás*
}

\begin{abstract}
The birthday of first Hungarian Rebuplic: Budapest, November 16, 1918. With the date of 16 November 1918, most people associate to the proclamation of the first Republic of Hungary at the Parliament, and certainly, the name of Mihály Károlyi comes to their minds.

This is no coincidence, as that was undoubtedly the most massive event of the day. However, the relevant events in the sense of public law did not take place in the square in front of the Parlament, but inside its building. This relevant event was the last session and dissolution of the Parlament, that operated continously since 1910, and last session and closure of the Upper House, that resulted the end of the parliamentary procedure. On the same day, during the session of the Council of Ministers, the Government decided on the name of the country as well. The plenum defined the state form as People's Republic. The Grand National Council, including the delegates of the county national councils, proclaimed the Republic during its first session in the Parlament's House of Cups and adopted its first people's resolutions. At the same time declared that October 31 and November 16 would be national holidays.
\end{abstract}

Keyworsd Great War (1914-1918), history of Central-Europe, History of Hungarian Kingdom at 1918

\section{Az országgyülés utolsó ülése és feloszlásának kimondása}

Az 1910 júniusában összeült országgyülés mandátuma 1915 nyarán járt volna le. Miután azonban az 1914-töl több fronton is háborúban álló országban az alkotmányos követelményeknek megfelelő választások lebonyolítása lehetetlen volt, a magyar országgyülés 1915-ben törvényben rendelkezett a képviselők mandátumának a háborút lezáró békekötést követő hatodik hónap végéig történő meghosszabbításáról. ${ }^{1} \mathrm{~A}$ képviselők ezáltal megtartották mandátumaikat, az országgyülés pedig működőképességét. Magyarország így egészen 1918 őszéig megmaradt parlamentáris monarchiának.

A fordulat akkor következett be, amikor 1918. október 23-án Wekerle Sándor miniszterelnök az egyre súlyosbodó katonai helyzetre hivatkozva bejelentette lemondását, $\mathrm{s}$ egyúttal egy olyan, valamennyi politikai erőt képviselő koncentrációs kormány alakítását

\footnotetext{
*Intézmény: Kodolányi János Egyetem Email: lvizi@kodolanyi.hu

${ }^{1}$ Az országgyülés tartamának kivételes meghosszabbításáról az 1915. évi IV. törvénycikk rendelkezett. A mindössze négy paragrafusból álló törvényt lásd https://net.jogtar.hu/ezer-ev-torveny?docid=91500004.TV\&searchUrl=/ezer-evtorvenyei\%3Fkeyword\%3D1915 [2018. augusztus]
} 
javasolta, amely képes az ország határainak megvédésére. ${ }^{2}$ Az országgyülés ülésnapját végül azzal zárta, hogy felhatalmazta Szász Károlyt, ${ }^{3}$ az országgyülés elnökét, hogy „amint annak lehetöségét és szükségét látja, a ház ülését egybehívja és hogy ezen legközelebbi ülés napirendjére egyedül a további teendők iránti intézkedés tétessék." 4 Akkor még mindenki abban bízott, hogy erre néhány napon belül sor kerülhet, $\mathrm{s}$ a kibontakozó kormányválság gyorsan megoldódik. Az események azonban felgyorsultak, s olyan - a magyar történelemben páratlan - egy hét következett, amelyet a magyar politikai elit képtelen volt kontrollálni, $\mathrm{s}$ tehetetlenül sodródott azzal az árral, amely elemi erővel söpörte el a fennálló politikai struktúrát. Ebből következően az országgyülés összehívására is csak több mint három hét elteltét követően került sor, s a jelenlévő képviselők olyan bejelentést kényszerültek tudomásul venni, amiről három héttel korábban még legmerészebb álmaikban sem gondoltak. Az országgyülés törvényi határidő elötti feloszlatásáról szóló javaslatot.

A Szász Károly országgyülési elnök által 1918. november 16-án, szombaton, délelőtt tíz órára összehívott ülés alig tartott mindössze öt percig. Az elnöklő Szász Károly, a mindössze néhány tucat képviselő jelenlétében, rövid beszédben utalt az elmúlt hetek eseményeire, ,az önálló, független, demokrata Magyarországnak,” a magyar nép által kinyilvánított igényére, majd annak a reményének adott hangot, hogy a kormány hazafias kötelességének fogja tartani az ország területi integritásának a megóvását. ${ }^{5}$ Utóbbi megjegyzésével utalt a házban október 23-án elhangzott miniszterelnöki beszédben elhangzottakra. Ezt követően azt a határozati javaslatot fogalmazta meg, hogy ,a magyar országgyülésnek ez a még 1910-ben összeült képviselőháza, a teljesen megváltozott viszonyokra tekintettel mondja ki feloszlását.”6 Az előterjesztést Sümegi Vilmos ${ }^{7}$ „Éljen a magyar köztársaság!” és Hock János ${ }^{8}$ „Meghalt már régen ez a képviselőház!” bekiabálásai kísérték. ${ }^{9}$ Miután a határozati javaslathoz hozzászóló felszólaló nem jelentkezett, az elnöklő Szász Károly vélelmezve a ház jelen lévő tagjainak a javaslat iránti teljes támogatását, azt a ház egyhangú határozataként jelentette ki, s egyúttal erről a főrendi házat értesítette. ${ }^{10}$

Jelen tanulmány terjedelme nem teszi lehetővé a fenti döntés részletes alkotmányossági vizsgálatát és elemzését. Ezért most csak utalunk annak legfontosabb alkotmányossági hiányosságaira. Nevezetesen az ülés határozatképességének kérdésére, a határozati javaslat megszavaztatásának elmaradására, valamint az 1915. évi IV.

\footnotetext{
${ }^{2}$ Az 1910-1915. évi országgyülés képviselőházának naplója. (a továbbiakban KN) XLI. kötet. 1918. július 24november 16. 447. old.; Wekerle lemondásának politikai hátterét ismerteti Görög Staub Károly-Patay Géza 2011, 219-222.

${ }^{3}$ A Veszprém vármegyei enyingi kerületben a Nemzeti Munkapárt programjával képviselővé választott Szász Károlyt (1865-1950) 1917. július 3-án titkos szavazással választották az országgyülés elnökévé. Közéleti tevékenységére lásd Sturm-féle országgyülési almanach 1910-1915. Szerk.: Végváry Ferenc-Zimmer Ferenc. Budapest, 1910. 423. old.; Szász Károly képviselöházi elnökké történő megválasztásának részleteit lásd KN XXXVI. kötet. 1917. június 21-július 23. 230-231. old.

${ }^{4}$ KN XLI. kötet. 1918. július 24-november 16. 449. old.

${ }^{5}$ KN XLI. kötet. 1918. július 24-november 16. 451. old.

${ }^{6}$ Uo.

7 Sümegi Vilmos 1904. november 4-én időközi választáson, függetlenségi és 48-as programmal került a gyergyószentmiklósi kerület képviselőjeként első ízben a törvényhozásba. 1905-ben és 1906-ban nagy többséggel ismét megválasztották. 1910. június 3-án negyedszer is képviselővé választották. Sturm-féle országgyülési almanach 1906-1911. Szerk.: Fabro Henrik-Ujlaki József. Budapest, 1906. 219-220. old.; Sturm-féle országgyülési almanach 1910-1915. 419-420. old.

8 Hock János (1859-1936) katolikus plébános, politikus és író. 1887-től folyamatosan tagja volt a képviselőháznak. 1889-től Budapesten kőbányai, majd 1912-től józsefvárosi plébános, a korszak egyik legnépszerübb egyházi szónoka (a kőbányai aranyszájú). Meggyőződéses pacifista és Károlyi Mihály egyik legközelebbi híve, a Magyar Nemzeti Tanács elnöke. Sturm-féle országgyülési almanach 1910-1915. $297-298$. old.

${ }^{9}$ KN XLI. kötet. 1918. július 24-november 16. 451. old.

${ }^{10} \mathrm{Uo}$.
} 
törvénycikk 3. §-ára, amely az országgyülés megszünésének időpontját a békekötést követő hatodik hónap végében deklarálta, s egyúttal elöírta az új országgyülés összehívására vonatkozó határidőt. Említendő továbbá, hogy a határozat figyelmen kívül hagyta az uralkodónak az országgyülés berekesztésével és feloszlatásával kapcsolatos jogait is. Bár utóbbi magyarázható IV. Károly 1918. november 13-i eckartsaui nyilatkozatának azon részével, mely szerint a király az államügyek vitelében minden részvételéről lemondott.

\section{A Főrendi Ház utolsó ülése és tanácskozásainak berekesztése}

A Főrendi Ház ülését 1918. november 16-án, 10 óra 15 perckor, báró Wlassics Gyula ${ }^{11}$ elnök nyitotta meg. Beszédét az elnök azzal kezdte, hogy utalt a maguk mögött hagyott napok, hetek eseményeire, amelyek vulkanikus erejü átalakulásokat generáltak, s amelyek kiemelkedő eseményeként Magyarország visszanyerte teljes függetlenségét. Egyúttal kijelölte az új kormány előtt álló legfontosabb feladatokat: „sikerüljön [...] a belső rendet és nyugalmat biztosítani, határainkat rabló betörésektöl megvédeni és oly békekötést elérhetővé tenni, melynek áldozatai közé hazánk területi integritása ne kerüljön." 12 Wlassics mintha megérezte volna a háború utáni béketárgyalások és békekötések során bekövetkező anomáliákat, már a békekonferencia megnyitása elött két hónappal figyelmeztetett arra, hogy ha nem születnek igazságos döntések, ha az új világrend ,az elkeseredés mérgével” lesz átitatva, akkor az új rend nem lehet és nem is lesz majd tartós. Wlassics pontosan látta, hogy milyen erősek a magyar állam területi megcsonkítására irányuló igények. Ezekkel szemben beszédében számos olyan érvet hozott fel, amelyeket majd gróf Apponyi Albert is felsorol abban az emlékezetes 1920. január 16-i híres beszédében.

A nemzetiségekkel kapcsolatban Wlassics megjegyezte, hogy azok nyelvi, kulturális és gazdasági fejlődését a magyar állam évszázadokon keresztül biztosította, s lehetővé tette számukra azok szabad múvelését. Ugyanakkor rendkívül önkritikusan bevallotta, hogy a magyar politikai vezetés is számos hibát elkövetett. Ezek a hibák azonban véleménye szerint kölcsönösek voltak. A kölcsönös hibák pedig kölcsönös sérelmeket indukáltak.

Wlassics beszédében hitet tett az ezeréves Magyarország területi integritása mellett, melyet európai érdekként jelölt meg, s ezt politikai, földrajzi, etnográfiai és gazdasági érvekkel indokolta. Ugyanakkor kijelentette, hogy „Mi készek vagyunk elmenni nem magyar ajkú polgártársaink kívánságainak teljesítésében a legmesszebb határokig." ${ }^{13}$ Nem kétséges, hogy Wlassics ezen utóbbi alatt a nemzetiségeknek nyújtandó területi autonómiát értette, természetesen a magyar állam keretein belül. Egyúttal a kisebbségek jogainak védelme érdekében általános elvek rögzítését javasolta. Vajon már arra is gondolt, hogy a békekötés következményeként milliónyi magyar kerül majd más államok fennhatósága alá, akiknek a jogait egységes, európai normák szerint kellene garantálni?

\footnotetext{
${ }^{11}$ Báró Wlassics Gyula (1852-1937) jogász, miniszter, akadémikus, országgyülési képviselő, a főrendiház, majd a felsőház elnöke. 1895 és 1903 között vallás- és közoktatásügyi miniszter, 1892-től 1905-ig négy ciklusban a Zala vármegyei Csáktornya szabadelvü párti országgyülési képviselője. 1906 és 1918 között a förendiház tagja volt. 1918. június 22-től 1918. november 16-ig a főrendiház elnöke. Wlassics Gyula közéleti politikai tevékenységére lásd Jónás Károly 2002, 245-249.; Kapiller Imre (szerk.) 2002; Szendrei Géza 2008, $159-163$.

${ }^{12} \mathrm{Az}$ 1910. évi június hó 21 -ére hirdetett Országgyülés Főrendiházának Naplója. V. kötet. Budapest, 1919. (a továbbiakban FN) 234. old.

${ }^{13}$ FN 235. old.
} 
Minden bizonnyal igen, hiszen beszéde folytatásaként utalt arra a wilsoni kinyilatkozásra, ${ }^{14}$ mely szerint „Népeket és tartományokat nem lehet az egyik állam felsőségéből egy másikba áttolni, mintha csupán tárgyakról, vagy kövekről volna szó valamely játékban." 15 Wlassics erre a wilsoni nyilatkozatra hivatkozva égbekiáltó igazságtalanságnak tartaná, ha Magyarország „földjét egyszerüen szabad prédának” tekintenék, mely, ha megvalósulna, semmiképpen sem szolgálná a világ békéjét. ${ }^{16}$

Ebben a rendkívüli helyzetben, Wlassics megfogalmazása szerint „,vészes időkben” a legteljesebb összefogásra szólította fel a politikai pártokat annak érdekében, „,nehogy ezek a veszélyek elháríthatatlan katasztrofális szerencsétlenséggé sürüsödjenek”. Felhívta a figyelmet, hogy „Oly időket élünk, melyekben csak az egyesült erő energiája menthet meg bennünket” s legfőbb érdekként az ország területi épségének megőrzést deklarálta. ${ }^{17}$

Beszéde végeztével Wlassics jelezte, hogy az ülést a képviselöház azon üzenetének átvétele céljával hívta össze, melyet Szász Károly képviselőházi elnök jegyzett és juttatott el hozzá. Miután Hertelendy Ferenc jegyző felolvasta a képviselőházi üzenetet, Wlassics Gyula az abban foglaltakat - nevezetesen, hogy a képviselőház magát feloszlottnak nyilvánította - a főrendi ház nevében tudomásul vette. Majd, mint az alkotmányjogban igazán otthonosan mozgó jogászprofesszor, a képviselőházi üzenet förendi házra vonatkozó joghatásait foglalta össze: „Minthogy pedig a törvényeink szerint két házból álló országgyülés képviselőházának feloszlatása természetszerüleg vonja maga után azt, hogy az országgyülés másik háza sem folytathatja alkotmányos müködését, a förendiház tanácskozásait ezennel berekesztetteknek nyilvánítom.”18 Ezzel az országgyülés müködése 1918. november 16-án 10 óra 25 perckor megszünt. Wlassics azonban Szász Károllyal ellentétben nem mondta ki a förendi ház feloszlatását, hanem annak munkáját csupán berekesztette. Ezáltal biztosította a jogfolytonosságot, amit az 1926. évi XXII. törvénycikk is elismert, s melynek alapján az 1926ban újjáalakult felsőház a förendi házat a maga alkotmányos jogelődjének tekinthette. ${ }^{19}$

\section{A minisztertanács 1918. november 16-i ülése}

A Károlyi Mihály miniszterelnök elnöklete alatt összeülö minisztertanács napirendjén tizenegy téma szerepelt. Több személyi jellegű kérdés - kormánybiztosi kinevezések, minisztériumi tisztségviselök hivatali címekkel való felruházás - mellett többek között döntés született például a király személye körüli miniszteri állás és a minisztérium megszüntetéséről, miniszterközi bizottság kiküldéséről a fegyverszüneti feltételek teljesítése végett, a Szerbiának okozott károk Ausztriával és Németországgal közös viseléséről, a hústalan napok eltörléséről stb. ${ }^{20}$

A negyedik napirendi pont keretében a miniszterelnök elöterjesztésére döntött a minisztertanács ,,a király kinevezési jogának kormányzati átvételéről, a kormány és az ország elnevezéséröl." ${ }^{21}$ Eszerint a „Ministerelnök úr előterjesztésére a ministertanács kimondja, hogy a jövőben azokat a kinevezéseket, amelyeket eddig a király eszközölt, illetve amelyekhez királyi hozzájárulás volt szükséges, a kormány fogja eszközölni

\footnotetext{
${ }^{14}$ Wilson fellépéséről és hatásáráról az Osztrák-Magyar Monarchia területén 1918 őszén lezajló eseményekre lásd Gulyás László-Szávai Ferenc 2018, 46-51.

${ }^{15}$ Uo.

${ }^{16}$ Uo.

${ }^{17}$ Uo.

${ }^{18}$ Uo.

19 1926. évi XXII. törvénycikk az országgyülés felsőházáról. https://net.jogtar.hu/ezer-ev-torveny?docid= 92600022.TV\&searchUrl=/ezer-ev-torvenyei\%3Fpagenum\%3D39 [2018. augusztus]

${ }^{20}$ Magyar Nemzeti Levéltár (MNL) Országos Levéltár (OL) Minisztertanácsi jegyzőkönyvek. Elektronikus Levéltári Portál. K27191811161001. - K27191811161010.

${ }^{21}$ MNL OL K27191811161003.
} 
ministertanácsban. A ministerium elnevezése: a magyar népköztársaság kormánya lesz. Az ország elnevezése: magyar népköztársaság."22

\section{A Nagy Nemzeti Tanács I. ülése}

\section{A köztársaság kikiáltása és elsö néphatározatok elfogadása az Országház kupolacsarnokában}

A vidéki nemzeti tanácsok küldötteit is magában foglaló Nagy Nemzeti Tanács 1918. november 16-án, délelőtt 11 órakor, a parlament kupolacsarnokában tartotta első ülését. ${ }^{23}$ Az ülésen Hock János, mint a Nemzeti Tanács elnöke elnökölt, a jegyzökönyvet Nagy György ügyvéd, az Országos Köztársasági Párt alapítója vezette. Jelen volt az ülésen gr. Károlyi Mihály miniszterelnökön kívül a kormány több tagja is. Jászi Oszkár tárca nélküli nemzetiségi miniszter, gr. Batthyány Tivadar belügyminiszter, Garami Ernő kereskedelemügyi miniszter, Kunfi Zsigmond tárca nélküli miniszter, Bartha Albert hadügyminiszter, Lovászy Márton vallás-és közoktatásügyi miniszter, Berinkey Dénes igazságügy miniszter, Nagy Ferenc közélelmezési miniszter, Szende Pál pénzügyminiszter és Buza Barna földmüvelésügyi miniszter. ${ }^{24}$

Az ülést az elnöklő Hock János, hủen a Kőbányán a hívek által ráaggatott „aranyszájú” jelzöhöz, hosszú, számos történelmi párhuzamot citáló, dagályos, barokkos körmondatokkal teletüzdelt beszéde vezette be. A beszéd végén tért rá a tényleges mondanivalójára, az összejövetel valódi céljára. Nevezetesen, hogy „kimondjuk [...] államformánk megváltoztatását: a szabad és független köztársaságot.”"25

A hosszúra nyúlt elnöki megnyitót követően Hock bejelentette a király lemondását, valamint a képviselőház és a förendiház feloszlását. Azzal az alkotmányjogi ,aprósággal” persze nem foglalkozott, hogy a förendiház nem feloszlott, hanem berekesztette müködését. A bejelentést követően a Nemzeti Tanács öt tagú végrehajtó bizottságának a nevében azt a döntést is közölte a hallgatósággal, hogy „ha ezen lemondások és feloszlatások meg nem történtek volna, a forradalom erejével ezeket mi megszüntettük volna."26

Hock ezt követően kimondta Magyarország önállóságát és függetlenségét, majd indítványozta „az államforma megváltoztatását és a köztársaság ünnepélyes proklamálását.” Egyidejüleg indítványozta október 31-e és november 16-a nemzeti ünneppé történő deklarálását, „és a nemzet történetét meggyalázó április 11-ét és a többi királyczafrangos” ünnep eltörlését. ${ }^{27}$

A Nemzeti Tanács végrehajtó bizottságának Néphatározati Javaslatait Nagy György jegyző olvasta fel. „Magyarország Nemzeti Tanácsa a nép akaratából a következő néphatározatot hozta:

„I. czikk. Magyarország minden más országtól független és önálló népköztársaság.

\footnotetext{
${ }^{22}$ MNL OL K27191811161003. - K27191811161004.

${ }^{23}$ Az ülés jegyzőkönyvét lásd KN XLI. kötet. 1918. július 24 -november 16. 455-463. old. A Nagy Nemzeti Tanács a vidéki nemzeti tanácsok, a forradalomhoz csatlakozó politikai pártok, a munkástanácsok és más munkásszervezetek, az érdekképviseletek, a rendör- és katonatanács, valamint különféle gazdasági és társadalmi egyesületek küldötteiböl állt össze. Nagyjából ezer tagja volt, akik a társadalom szinte minden rétegét képviselték. A testület nem választás, hanem delegálás útján jött létre, ami legitimitását erősen megkérdőjelezte.

${ }^{24}$ Bölöny József, Hubai László 2004, 89-90.

${ }^{25}$ KN XLI. kötet. 1918. július 24 -november 16. 457. old.

${ }^{26}$ Uo.

${ }^{27}$ Uo.
} 
II. czikk. A népköztársasági alkotmányt új választójog alapján sürgősen egybehívandó alkotmányozó nemzetgyülés állapítja meg. A magyar országgyülés képviselőháza és főrendiháza feloszlik és megszünik.

III. czikk. Addig, míg az alkotmányozó nemzetgyülés másként nem határoz, az állami föhatalmat a Károlyi Mihály elnöklete alatt álló népkormány gyakorolja, a Magyar Nemzeti Tanács intézőbizottságának támogatásával.

IV. czikk. A népkormány alkosson sürgősen néptörvényeket: 1 . Az általános, titkos, egyenlő, közvetlen és a nőkre is kiterjedő nemzetgyülési, törvényhatósági és községi választójogról, 2. a sajtószabadságról, 3. a nép esküdtbíráskodásáról, 4. az egyesülés és gyülekezés szabadságáról, 5. a földmíves népnek földhöz juttatásáról.”28

A IV. cikkhez kapcsolódóan az elnök hozzáfüzte „hogy a néptanács intézőbizottsága javasolja, hogy az összes államhatalmat ráruházzák a kormányra a Nemzeti Tanács intézőbizottságának támogatásával és azzal a korlátozással, hogy a határozati javaslatban felsorolt törvényeket azonnal bocsássák ki és azok végrehajtásáról mielőbb gondoskodjanak." 29

A Néphatározati Javaslatok V. cikke arról rendelkezett, hogy az előzőkben elfogadott cikkekkel ellentétes „törvényes rendelkezések hatálya megszünik, minden egyéb törvényes rendelkezés hatályban marad." 30

A magát nemzetgyülésnek deklaráló Nagy Nemzeti Tanács valamennyi elöterjesztést közfelkiáltással fogadta el.

Végezetül az elnök az elfogadott második cikkhez kapcsolódóan azt a kijelentést tette, hogy az alkotmányozó nemzetgyülés az általános, egyenlö, titkos választójog alapján ${ }^{31}$ akkor kerül majd összehívásra, amikor a nemzet szabadon választhat. Hogy ez alatt Hock János konkrétan mit értett, azt nem fejtette ki. A békeszerződés utáni időszakra gondolt e, vagy valami másra, esetleg az ország területi integritásának a csorbulásából adódó alkotmányjogi helyzetre, hozzászólásából nem derült ki. ${ }^{32}$ Kiegészítő hozzászólásában csupán arra utalt még, hogy a köztársasági alkotmány alapelveinek kidolgozásáról és a hatalom megosztásáról az újonnan megalakuló nemzetgyülésnek kell majd döntenie, mely reményei szerint egykamarás lesz. ${ }^{33}$

Az ülésen ezt követően beszédet mondott Károlyi Mihály miniszterelnök és a szociáldemokrata kormánytag Kunfi Zsigmond. Károlyi a pacifista, demokratikus és szociális alapon nyugvó kormányprogramot helyezte beszédének fókuszába, miközben a múlt romba döntéséről polemizált. Követendő elvként a wilsoni elveket hangsúlyozta, a népek önrendelkezési jogát, s ,,hogy mindenki maga határozzon saját sorsa felett.. ${ }^{34}$ Ha ezt hallották vagy olvasták az ország területét szétszabdalni kívánó politikai erők, bizony dörzsölhették tenyerüket. Károlyi beszédében utalt arra, hogy kormányának bel- és külpolitikáját nyitott könyvként képzeli el, s ennek deklarálása céljából kérte, hogy a Nagy Nemzeti Tanács fogadja el az általa javasolt a „Minden civilizált nemzethez!” című szikratávirat szövegét. A szikratávirat utalt a magyarság Habsburg-ellenes szabadságküzdelmeire, s rögzítette, hogy ,a magyar népet a múlt büneiért nem terheli felelösség." ${ }^{35}$ Hangsúlyozta, hogy minden demokratikus fejlődés akadálya a kiegyezés volt, de a wilsoni alapokon megszülető Magyar

\footnotetext{
${ }^{28}$ KN XLI. kötet. 1918. július 24-november 16. 457-458. old.

${ }^{29}$ Uo. 458 . old.

${ }^{30}$ Uo.

31 Az általános, titkos, egyenlő, közvetlen, nőkre is kiterjedő választójogról az 1918. évi I. néptörvény rendelkezett, amelyet 1918. november 23-án hirdettek ki. https://net.jogtar.hu/ezer-ev-torveny?docid= 91800201.TV\&searchUrl=/ezer-ev-torvenyei?pagenum $=38$ [2018. augusztus]

${ }^{32}$ Az alkotmányozó nemzetgyülési választások időpontját a kormány 1919. április 24-ben határozta meg. Addigra azonban Károlyi és a polgári demokratikus koalíció kormánya megbukott.

${ }^{33}$ KN XLI. kötet. 1918. július 24-november 16. 458. old.

${ }^{34}$ Uo. 459. old.

${ }^{35}$ Uo. 460. old.
} 
Népköztársaság ,a legteljesebb és legtisztább demokrácia szellemében akarja Magyarország viszonyait újjárendezni és bízik benne, hogy a felszabadult néperők ezen alapon meg fogják találni az együttes, békés, testvéri munkának a lehetőségét." ${ }^{36}$ Igyekezzünk leszögezni, hogy Károlyinak mindezekben nagyon gyorsan csalatkoznia kellett!

Károlyi után a szociáldemokrata Kunfi Zsigmond emelkedett szólásra, aki beszédében a forradalmi szociáldemokrácia eszméit hirdette meg, $\mathrm{s}$ a nemzetközi proletariátus internacionalista szolidaritására épülő új világot vizionált. Kunfi beszédében egyértelművé tette, hogy az elért politikai demokráciát csak eszköznek tekinti, hiszen a forradalmi folyamat álláspontja szerint még nem bejezett. Kifejtette, hogy pártjának célja a nemzetközi proletariátussal karöltve ,a nagy szocziális átalakulást megcsinálni.” Beszédét, amely a szociális forradalom nyílt programja és propagandája volt az „Éljen a forradalmi szociáldemokrácia!" bekiabálás tette még nyomatékosabbá. ${ }^{37}$ Nem véletlenül jegyezte meg a beszédről és a szónokról Tormay Cécile írónő, hogy „A magyar parlament ünnepi termében, Lenin ágense, kényelmesen kibonthatta a bolsevizmus zászlaját, megfújhatta a szociális forradalom riadóját és hirdethette a világforradalom eljövetelét [...]"38

A Nagy Nemzeti Tanács mintegy másfél óra hosszúságú ülését az elnöklő Hock János 12 óra 30 perckor az „Éljen a szabad, független, magyar köztársaság!” felkiáltással zárta be. ${ }^{39}$

\section{A köztársaság kikiáltása az Országház téren}

Még tartott a Nagy Nemzeti Tanács ülése, amikor Károlyi Mihály beszédét követően az elnöklő Hock János arról tájékoztatta a résztvevőket, hogy az előzetes egyeztetéseknek megfelelően, a parlament előtt álló tömeggel pontban 12 órakor ismertetni kívánják az elfogadott határozatokat. Ezek felolvasására és megmagyarázására felkérte Bokányi Dezsőt, Jászi Oszkárt és Lovászy Mártont, akik elhagyták a kupolacsarnokot, s hírül vitték azt a parlament előtti Országház téren tolongó tömegnek. ${ }^{40}$

A hírt, hogy a köztársaságot november 16-án, szombaton a parlament előtt proklamálni fogják, már az előző napon megjelenő lapok közölték. ${ }^{41}$ A november 16-i és 17-i budapesti és vidéki lapok pedig kivétel nélkül részletes tudósítást adtak az eseményekröl. ${ }^{42} \mathrm{~A}$ budapesti munkásságot a szociáldemokrata párt aktivistái és a szakszervezeti bizalmiak az üzemekből és gyárakból vörös zászlók alatt és zárt sorokban vonultatták a parlament előtti Országház térre, ahová délelőtt tizenegy óra körül érkeztek. A térre kirendelték a föiskolai hallgatókat és a középiskolai tanulókat is. Ök a múzeumkertben gyülekeztek, s rendezett sorokban érkeztek a parlament elé. ${ }^{43} \mathrm{Az}$ utcákon közben röplapokat osztogattak, amelyeken a független köztársaságot éltették. Röplapokat a tér és a belváros felett körözö repülögépekröl is dobáltak. A téren munkás-és postászenekarok, cigánybandák és dalárdák adták a zenei aláfestést. A parlament épületét a szemben lévő házakat, a Kúria és a Földművelésügyi Minisztérium épületét vörös drapériával díszítették.

\footnotetext{
${ }^{36}$ Uo.

${ }^{37}$ Uo. 461-463. old.

${ }^{38}$ Tormay Cécile (2010): Bujdosó könyv. Feljegyzések 1918-1919-ből. Könyv-e.hu. Elektronikus Könyvtár. 150. old.

${ }^{39}$ KN XLI. kötet. 1918. július 24-november 16. 463. old.

${ }^{40}$ Uo. 460. old.

${ }^{41}$ Budapesti Hirlap, XXXVIII. évf. 268. sz. 1. old.

${ }^{42}$ Erre néhány példa a teljesség igénye nélkül: 8 Órai Ujság, Magyarország, Pesti Hirlap, Az Est, Budapesti

Hírlap, Dunántúl, Friss Ujság, Népszava, Pécsi lapok, Pécsi Napló, Az Ujság, Vasárnapi Újság, Világ.

${ }^{43}$ Az Ujság, XVI. évf. 269. sz. 2. old.
} 
A Budapesti Hirlap a téren történt eseményekröl az alábbi beszámolót tette közzé: „Pontosan tizenkét óra volt, a mikor a képviselőház erkélyén az örömtől mámoros tömeg előtt, mely a téren várakozott, megjelentek Bokányi Dezső és Jászi Oszkár nemzetiségi miniszter. A tömeg éljen riadalba tört ki, mire Bokányi Dezső az emelvényre lépett és kihirdette a kupola-teremben hozott határozatokat. Százezer kar emelkedett a levegőbe és negyedóráig zugott és tombolt a vihar s az emberek egymás nyakába borulva éltették a köztársaságot. A katonazenekar a Himnuszt, majd a Marseillaisét játszotta, a melyet a tömeg együtt énekelt a zenekarral. Utána Jászi Oszkár, Lovászy Márton és Kernstok Károly szólottak a népnek. Félegy óra volt, a mikor a föbejárat lépcsőjén megjelent Károlyi Mihály gróf és Hock János kíséretükben a kormány tagjaival. A tömeg orkánszerü éljenzéssel fogadta, kalapok, zsebkendők tízezrei lobogtak a levegőben s viharosan zúgott a taps, hangzott a kiáltás: Éljen a köztársaság! Éljen Károlyi Mihály!" 44 A tömeghez elöbb Károlyi, majd Hock, végül Garami Ernő kereskedelmi miniszter szólott, az erre a célra elkészített vörös drapériával borított emelvényről. Mindhárman a forradalom győzelmét éltették és a népköztársaság jelentőségét hangoztatták. A beszédeket követően „Ujra kitört az éljenzés, a katonazenekar pedig rázenditett a Marseillaisesre. még zúgott a tömeg és harsogott az éljenzés, amikor Károlyi Mihály gróf lement a lépcsőkön az örömmámorban úszó tömeg közé. Az emberek vállukra kapták $\mathrm{s}$ éljenezve vitték magukkal az Alkotmány-utca felé, a hol végre is eltünt a tömegben. Ezzel a nemzeti ünnep véget is ért és a tömeg a legnagyobb rendben szétoszlott." 45

$\mathrm{Az}$ eseményeket a téren szorgalmasan forgató filmesek is dokumentálták, melyeket aztán az alábbi inzertszövegek kíséretében a filmhíradókban tettek közzé: „A Magyar Köztársaság proklamálása 1918. november 16-án. A forradalmi himnusz. Monstre cigányzenekar. Magyar Himnusz. Dr. Dietz Károly főkapitány és vezérkara. Hock János beszél a néphez. Bokányi Dezső kihirdeti a nép előtt a Nemzeti Tanács néphatározatát. Lovászy Márton kultuszminiszter beszél. A diadalmas Köztársasági Párt első zászlója, középen Kossuth Lajos képével. Éljen a Köztársaság! Szirmay György 48as honvéd föhadnagy, akihez Hock János a Nemzeti Tanács ülésén beszédet intézett, a jelenet nagyszerüségétől meghatva sírva fakad. Károlyi Mihály miniszterelnök beszél. Károlyi diadalútja."46

Az 1918. november 16-i nap mozgalmas és felkavaró döntéseinek és eseményeinek ellentmondásosságát jól jellemzi az alábbi anekdota: „A vidékről véletlenül odavetődött néhány parasztgazda kopogós csizmában, hallgatagon ment a Belváros felé. [...] A parasztok sokáig mentek szótlanul. Aztán végre az egyik öreg gazda meggondoltan, lassan odaszólt a többihez: - Hát szép dolog ez a köztársaság, de már most azt szeretném tudni, hogy ki lesz a király?"47

Ugyanakkor jegyezzük meg, hogy a forradalmakat követö ellenforradalmi rendszer fontosnak tartotta, hogy 1918. november 16-ra méltó választ adjon, s egyúttal leszámoljon annak eszmei örökségével. Erre már pontosan egy év múlva sor is került, amikor 1919.

\footnotetext{
${ }^{44}$ Budapesti Hirlap, XXXVIII. évf. 270. sz. 6. old.

${ }^{45}$ Uo.

${ }^{46}$ http://filmhiradokonline.hu/watch.php?id=5347; http://filmhiradokonline.hu/watch.php?id=5439; http://filmhiradokonline.hu/watch.php?id=5431; http://filmhiradokonline.hu/watch.php?id=5363; http://filmhiradokonline.hu/watch.php?id=5349; http://filmhiradokonline.hu/watch.php?id=5350; http://filmhiradokonline.hu/watch.php?id=5351 [2018. augusztus]

${ }^{47}$ Tormay Cécile 2010, 151-152.
} 
november 16-án a románok által kiürített Budapestre bevonult a Horthy Miklós fővezér vezette Nemzeti Hadsereg. ${ }^{48}$

\section{Felhasznált irodalom}

Bölöny József, Hubai László 2004, Magyarország kormányai 1848-2004. Akadémiai Kiadó, Budapest.

FN: Országgyülés Főrendiházának Naplója. V. kötet. Budapest, 1919.

Görög Staub Károly-Patay Géza 2001, Wekerle Sándor. Helikon Kiadó, Budapest.

Gulyás László-Szávai Ferenc (2018): Közép-Európa és Wilson 14 pontja. BBC History 2018/október 46-51. old.

http://filmhiradokonline.hu/watch.php?id=5347

http://filmhiradokonline.hu/watch.php?id=5439

http://filmhiradokonline.hu/watch.php?id=5349

http://filmhiradokonline.hu/watch.php?id=5350

http://filmhiradokonline.hu/watch.php?id=5351

http://filmhiradokonline.hu/watch.php?id=5431

http://filmhiradokonline.hu/watch.php?id=5363

https://net.jogtar.hu/ezer-ev-torveny?docid=91500004.TV\&searchUrl=/ezer-evtorvenyei\%3Fkeyword\%3D1915

https://net.jogtar.hu/ezer-ev-torveny?docid=91800201.TV\&searchUrl=/ezer-evtorvenyei?pagenum $=38$

https://net.jogtar.hu/ezer-ev-torveny?docid=92600022.TV\&searchUrl=/ezer-evtorvenyei\%3Fpagenum\%3D39

Jónás Károly 2002, Báró Wlassics Gyula. In: Jónás Károly-Villám Judit 2002, A Magyar Országgyülés elnökei, 1848-2002. Budapest: Almanach. 245-249. old.

Kapiller Imre (szerk.) 2002, Wlassics Gyula és kora. 1852-1937. Millecentenáriumi Közalapítvány, Zalaegerszeg.

KN: Az 1910-1915. évi országgyülés képviselöházának naplója.

Magyar Nemzeti Levéltár (MNL) Országos Levéltár (OL) Minisztertanácsi jegyzökönyvek. Elektronikus Levéltári Portál. K27191811161001. K27191811161010.

Sturm-féle országgyülési almanach 1906-1911. Szerk.: Fabro Henrik - Ujlaki József. Budapest, 1906.

Sturm-féle országgyülési almanach 1910-1915. Szerk.: Végváry Ferenc - Zimmer Ferenc. Budapest, 1910.

Szendrei Géza 2008, Híres emberek, régi ügyészek. Rejtjel Kiadó, Budapest.

Vörös Boldizsár 2009, A magyar köztársaság kikiáltása 1918. november 16-án: szimbolikus helyfoglalás térben és időben. Közép-Európai Közlemények, II. évfolyam 2. sz. No. 4-5. 100-106. old.

A müre a Creative Commons 4.0 standard licenc alábbi típusa vonatkozik: CC-BY-NC-ND-4.0.

\section{$(\mathrm{CC}) \mathrm{BY}-\mathrm{NC}-\mathrm{ND}$}

\footnotetext{
${ }^{48}$ Vörös Boldizsár 2009, 100-106.
} 